\title{
Effect of solar radiation on photosynthetic extracellular carbon release and its microbial utilization in alpine and Arctic lakes
}

\author{
Michaela Panzenböck* \\ Department of Freshwater Ecology, University of Vienna, Althanstr. 14, 1090 Vienna, Austria
}

\begin{abstract}
The effect of solar radiation (photosynthetically active radiation and ultraviolet radiation [UVR]) on the photosynthetic extracellular release (PER) of phytoplankton and its utilization by bacterioplankton were studied in an alpine lake (Gossenköllesee, Austria) over a seasonal cycle. For comparison, 2 Arctic lakes on the Taymir Peninsula (Siberia) were investigated as well. The contribution of PER to primary production (\% net PER) ranged between 0 and $95 \%$ (mean $32 \%$ ) in Gossenköllesee (May 1999 to July 2000) following a seasonal trend that was inversely related to phytoplankton biomass. PER was released only under light conditions and was positively related to the intensity of solar radiation. During the ice-covered period, the \% net PER increased, while total primary production $\left(\mathrm{P}_{\text {tot }}\right)$ decreased with experimentally increasing irradiance, indicating radiationinduced stress with dark-adapted phytoplankton. During the ice-free period, the increase of \% net PER with increasing irradiance was independent of photoinhibition. The fraction of PER not immediately incorporated by bacteria ( $60 \%$ of total PER) may be an important contribution to the generally low pool of dissolved organic carbon (DOC) in Gossenköllesee. At the Arctic site, net PER amounted to $21 \%$ of $\mathrm{P}_{\text {tot }}$ in an ice-free lake and $51 \%$ in the ice-covered Lake Nyagamya. In all lakes, the amount of PER was sufficient to meet the bacterial carbon demand. The UVR-induced inhibition of primary production in the investigated lakes was inversely related to the DOC concentration of the water column, with the lowest effect in the ice-free Arctic lake (3.5\% reduction of $\mathrm{P}_{\text {tot }}$ ) and the highest impact in the alpine lake (56\% reduction of $\mathrm{P}_{\text {tot, }} 61 \%$ reduction of PER); the percentage of net PER was apparently not controlled by UVR. This suggests that the investigated alpine lake is more sensitive to changes in UVR than the Arctic lakes are.
\end{abstract}

KEY WORDS: Primary production $\cdot$ PAR $\cdot$ UVR $\cdot$ Exudates $\cdot$ Carbon flux

\section{INTRODUCTION}

Planktonic algae release substantial amounts of photosynthesized carbon. While at least some part of this photosynthetic extracellular release (PER) is caused by cell death due to autolysis (Wetzel et al. 1972, Berman \& Wynne 2005), viral lysis (Brussaard 2004), or grazing (Lambert 1978), there is also evidence of carbon exudation by actively growing algae (Blaauboer et al. 1982, Baines \& Pace 1991). The reasons why intact cells exude photosynthetically fixed carbon are still uncertain. According to Bjørnsen (1988), PER occurs due to passive diffusion, a mecha- nism related to algal cell size and concentration differences between inside and outside the cell. It has also been suggested, however, that PER is an overflow reaction, i.e. algal carbon fixation exceeds synthesis of new cell material during periods of sufficient irradiance under nutrient-depleted conditions (Fogg et al. 1965, Berman-Frank \& Dubinsky 1999). Furthermore, PER is thought to create bacteria- and nutrientenriched microzones around algal cells (Azam \& Cho 1987), which can act as a protection shield against viral infection (Berman-Frank \& Dubinsky 1999). Specific compounds released by phytoplankton also cause allelopathy (von Elert \& Jüttner 1997) or build up the 
mucopolysaccharide matrix of colony-forming species (Hellebust 1974). There is evidence that the amount of PER of phytoplankton depends on the species composition (Blaauboer et al. 1982, Lancelot 1983), cell size (Biddanda \& Benner 1997), nutrient status (Lancelot 1983, Obernosterer \& Herndl 1995), productivity of the system (Cole et al. 1982, Baines \& Pace 1991), temperature (Watanabe 1980), and solar radiation (e.g. Mague et al. 1980, Watanabe 1980).

However, solar radiation as a governing factor of PER still remains poorly understood. For instance, Berman (1976) and Coveney (1982) found the highest PER contribution to total primary production (\% PER) in light-limited zones, whereas according to Fogg et al. (1965), \% PER increases with irradiance, suggesting that photoinhibition stimulates PER. Elevated PER, measured as the percentage of total primary production $\left(\mathrm{P}_{\text {tot }}\right)$, has been found under both extremely high and low irradiances (Mague et al. 1980, Watanabe 1980, Lee \& Rhee 1999). In other studies, however, no such relationship between \% PER and irradiance was found (Lancelot 1983, Giroldo \& Vieira 1999).

Since PER can be responsible for a substantial part of the total flux of dissolved organic carbon (DOC) through bacterioplankton (e.g. Cole et al. 1982), the amount of PER released by phytoplankton determines bacterioplankton production in lakes with little macrophyte biomass and reduced input of allochthonous DOC, such as in alpine (Sommaruga et al. 1999) and many Arctic lakes (Laurion et al. 1997, Ellis-Evans et al. 2001). Therefore, factors like radiation (photosynthetically active radiation [PAR] and ultraviolet radiation [UVR]) controlling primary production and extracellular release of photosynthesized carbon may influence bacterial utilization of PER and consequently the whole food web (Rae \& Vincent 1998) and should gain attention especially with respect to global change. For Arctic and alpine regions, drastic impacts of global warming are predicted (Beniston et al. 1997), leading, for instance, to an earlier melting of the ice cover (Livingstone 1997), and consequently to a prolonged exposure to radiation. Furthermore, lakes of elevated latitudes and altitudes are mostly affected by increasing UVR (Blumthaler et al. 1992, Vincent \& Pienitz 1996). The role of UVR on PER has only recently received attention (Pausz \& Herndl 1999, Carrillo et al. 2002).

Within the water column, PER contributes to the DOC pool, which, in turn, determines the transmission of solar radiation in aquatic ecosystems (e.g. Scully \& Lean 1994, Laurion et al. 2000). Compared to light attenuation of allochthonous DOC, the attenuation of PER is low because it contains much less highly absorbing chromophoric dissolved organic matter (CDOM; McKnight et al. 1994). However, the attenua- tion by PER could be relevant in low DOC lakes (Sommaruga \& Augustin 2006). Recently, DOC low in aromatic compounds was found to increase its light absorbing capacity during exposure to solar radiation (Reche et al. 2001, Reitner et al. 2002).

The present study was carried out to investigate the influence of PAR and UVR on planktonic primary production, on PER production, and on the utilization of PER by bacterioplankton in an alpine lake and 2 Arctic lakes. Carbon fluxes through phyto- and bacterioplankton as influenced by irradiance (PAR, UVR) were estimated over a period of 15 mo both in situ and under laboratory conditions in the Alps and during summer in the Arctic.

\section{MATERIALS AND METHODS}

Study sites. Gossenköllesee (GKS) is a small lake (area: $0.017 \mathrm{~km}^{2}$, maximum depth: $9.9 \mathrm{~m}$ ) located above the timber line ( $2417 \mathrm{~m}$ above sea level) in the Central Alps, Austria $\left(47^{\circ} 13^{\prime} \mathrm{N}, 11^{\circ} 01^{\prime} \mathrm{E}\right)$, and is ice covered for about 8 to 9 mo (see Sommaruga \& Augustin 2006 for details). Sampling was performed on 8 occasions between May 1999 and July 2000. The 2 Arctic lakes are situated on the Taymir Peninsula (Siberia, Russia) and were sampled in July 2000. The unnamed lake (LI, $70^{\circ} 17.4^{\prime} \mathrm{N}, 88^{\circ} 30.7^{\prime} \mathrm{E}$ ) has an approximate area of $0.025 \mathrm{~km}^{2}$, a maximum depth of $6 \mathrm{~m}$, and was ice-free during the investigation period. It is located at the forest-tundra zone with southern shrubby tundra and larch forest. Lake Nyagamya (NYA, $72^{\circ} 42^{\prime} \mathrm{N}$, $88^{\circ} 20^{\prime} \mathrm{E}$ ) was still covered with 1 to $1.9 \mathrm{~m}$ of ice during sampling, but this lake usually loses its ice cover during summer (T. Walasova pers. comm.). NYA is a large lake $\left(48 \mathrm{~km}^{2}\right)$ of unknown depth, surrounded by typical tundra with mesic graminoid herbaceous vegetation.

Samples were collected with a 1.51 Ruttner bottle, either from a boat or from the ice. Samples in GKS were collected from 3, 5, and $7 \mathrm{~m}$ depth at the deepest part of the lake. In LI and NYA, sampling depths were 3 and $2.5 \mathrm{~m}$, respectively.

Experimental design. To estimate in situ primary production in GKS, samples of 3,5, and $7 \mathrm{~m}$ (in triplicate and 1 dark control bottle) were incubated in $100 \mathrm{ml}$ glass bottles at the depth of collection for $5 \mathrm{~h}$.

To test whether PER is a light-dependent process, time courses of primary production were performed 3 times in GKS (0.5 to $10 \mathrm{~h}$ incubation) and once in each of the Arctic lakes (6 to $24 \mathrm{~h}$ incubation). Samples of $3 \mathrm{~m}$ depth were exposed in glass bottles continuously to surface radiation or $3 \mathrm{~h}$ (GKS) or $6 \mathrm{~h}$ (LI, NYA) to surface radiation and subsequently to the dark, respectively. Primary production fractionated as de- 
scribed below was estimated at several time intervals (duplicate samples each). These experiments also provide information on the distribution of phyto- and bacterioplankton within the size classes used for particulate primary production.

For the radiation experiments with PAR performed 8 times in GKS, duplicate samples in glass bottles (sampling depth: $3 \mathrm{~m}$ ) were incubated at the lake surface in a tray for $6 \mathrm{~h}$. There, each bottle was covered by different layers of wire netting to reduce incoming irradiance to $30,5,2.5$, and $1 \%$ of surface irradiance. Two additional samples were exposed to full sunlight (100\% of surface irradiance).

In July 2000, additional primary production measurements were performed in the presence of UVR to test the effects of UVR on photosynthesis and PER. Triplicate samples in quartz (UVR) or glass bottles (PAR) were incubated to full sunlight for 3, 6, and $10 \mathrm{~h}$ in GKS. The same experiments with incubations of 6 , 18, and $24 \mathrm{~h}$ were performed in the Arctic lakes.

Primary production, PER, and phytoplankton biomass. Primary production was measured using the ${ }^{14} \mathrm{C}$ method (Parsons et al. 1984). Samples were incubated with $1 \mu \mathrm{Ci}{ }^{14} \mathrm{C}$-sodium bicarbonate (specific activity $55 \mathrm{mCi} \mathrm{mmol}^{-1}$, American Radiolabeled Chemicals) in either $100 \mathrm{ml}$ glass bottles for the experiments with PAR (in situ measurements, radiation experiments) or in $100 \mathrm{ml}$ quartz bottles for experiments with UVR (July 2000). In each experiment, 2 dark control bottles were included.

After incubation, $5 \mathrm{ml}$ subsamples were transferred into scintillation vials to estimate $\mathrm{P}_{\text {tot }}$. Furthermore, $\mathrm{P}_{\text {tot }}$ was divided into 3 fractions: a particulate fraction comprising carbon fixed by phytoplankton, a particulate fraction comprising PER incorporated by bacterioplankton ( $\left.\mathrm{P}_{\text {part 1 }}, \mathrm{P}_{\text {part 2 }}\right)$, and the dissolved fraction (PER; Table 1). These fractions were determined by serial filtration (pressure <100 mbar) as mostly applied for primary production fractionation (e.g. Carrillo et al.

Table 1. Estimations of the different fractions of primary production

\begin{tabular}{|c|c|}
\hline Fraction & Definition \\
\hline$P_{\text {tot }}$ & $\begin{array}{l}\text { Total net primary production estimated } \\
\text { in the whole liquid sample }\end{array}$ \\
\hline $\mathrm{P}_{\text {part } 1}$ & $\begin{array}{l}\text { Particulate primary production, } \\
\text { estimated on } 1.2 \mu \mathrm{m} \text { filters }\end{array}$ \\
\hline $\mathrm{P}_{\text {part } 2}$ & $\begin{array}{l}\text { Particulate primary production }<1.2 \mu \mathrm{m} \text {, } \\
\text { estimated on } 0.2 \mu \mathrm{m} \text { filters }\end{array}$ \\
\hline net PER & $\begin{array}{l}\text { Calculated PER by substracting } \mathrm{P}_{\text {part } 1} \text { and } \\
\mathrm{P}_{\text {part } 2} \text { from } \mathrm{P}_{\text {tot }}\end{array}$ \\
\hline$\%$ net PER & Contribution of net PER to $\mathrm{P}_{\text {tot }}$ \\
\hline
\end{tabular}

2002, Descy et al. 2002). There, $95 \mathrm{ml}$ of the sample were filtered through $1.2 \mu \mathrm{m}\left(\mathrm{P}_{\text {part 1 }}\right)$ and $0.2 \mu \mathrm{m}\left(\mathrm{P}_{\text {part 2 }}\right)$ polycarbonate filters (Millipore Isopore RTTP and GTTP filters). Initially, parallel filtration was also performed. Two different samples were filtered onto 1.2 and $0.2 \mu \mathrm{m}$ pore size polycarbonate filters, respectively, and the $\mathrm{P}_{\text {part } 2}$ was calculated as the difference. The results of these 2 methods did not significantly differ; therefore, serial filtration was used for all experiments. Before September 1999, primary production was only partitioned into particulate carbon $(>0.2 \mu \mathrm{m})$ and PER $(<0.2 \mu \mathrm{m})$. Filters were rinsed with GF/F filtered lake water and placed into scintillation vials for radioassays. Before rinsing, $5 \mathrm{ml}$ of the filtrate representing PER were transferred to separate scintillation vials. To the scintillation vials, $100 \mu 1 \mathrm{~N} \mathrm{HCl}$ was added and the vials were left open for $24 \mathrm{~h}$ to remove inorganic carbon (Lignell 1992). Before the analysis, $5 \mathrm{ml}$ of scintillation cocktail (Canberra Packard, Ultima Gold) were added to the filters and $10 \mathrm{ml}$ to the liquid samples. Radioactivity was measured in a liquid scintillation counter (Canberra Packard, TriCarb 2000) after $10 \mathrm{~h}$. Quenching was corrected by the external standard ratio. For calculation, the disintegration per min (DPM) values of the dark samples were subtracted from the solar radiation-exposed samples. To calculate primary production, the formula given by Wetzel (1995) was used. Total dissolved inorganic carbon (DIC) was calculated from the alkalinity and $\mathrm{pH}$ measurements.

PER was also calculated by subtracting the particulate fractions from $\mathrm{P}_{\text {tot }}$ (Table 1), since the calculated and the estimated values for PER were in good agreement as tested during the initial period of the investigation.

Chlorophyll (chl a) was determined from 11 samples of each sampling depth $(3,5,7 \mathrm{~m})$ filtered on $47 \mathrm{~mm}$ Whatman GF/F filters. The filters were kept frozen until analysis. Chl a was extracted with ethanol $\left(4^{\circ} \mathrm{C}\right.$, $24 \mathrm{~h})$. The extract was GF/F filtered and measured fluorometrically (Strickland \& Parsons 1972) with a Shimadzu RF 1501 spectrofluorometer. Chl a extracted from spinach (Sigma) was used as standard. For the Arctic lakes, chl a was extracted with dimethyl sulfoxide (DMSO), and the GF/F filtered extract was measured with a field spectrophotometer (Spectronic mini 20, Bausch \& Lomb).

At several dates, parallel samples for chl a were filtered through $1.2 \mu \mathrm{m}$ polycarbonate filters, and the values were compared to the results obtained by the GF/F filters to examine the amount of picophytoplankton passing through the $1.2 \mu \mathrm{m}$ filter.

Bacterial production and bacterial abundance. Measurements of bacterial production via leucine(Simon \& Azam 1989) and thymidine-incorporation 
(Fuhrman \& Azam 1980) were performed at the same dates and temperatures as primary production to examine whether $\mathrm{P}_{\text {part } 2}$ represents bacteria incorporating PER during the incubation. Triplicate subsamples (10 ml) and 2 formalin-killed blanks were incubated with $\left[{ }^{3} \mathrm{H}\right]$-thymidine (specific activity $84.7 \mathrm{Ci} \mathrm{mmol}^{-1}$, final concentration $10 \mathrm{nmol}^{-1}$ ) or $\left[{ }^{3} \mathrm{H}\right]$-leucine (specific activity $120 \mathrm{Ci} \mathrm{mmol}^{-1}$, final concentration $20 \mathrm{nmol} \mathrm{l}^{-1}$ ) in the dark at in situ temperature for $4 \mathrm{~h}$. Bacteria were filtered onto cellulose nitrate filters (Millipore HA, $0.45 \mu \mathrm{m}$ pore size) and treated with $10 \mathrm{ml}$ ice-cold $5 \%$ trichloroacetic acid (Sigma Chemicals) for $10 \mathrm{~min}$. The filters were transferred into scintillation vials, dissolved in $1 \mathrm{ml}$ ethylacetate, supplemented with $5 \mathrm{ml}$ scintillation cocktail, and then radioassayed (see above). Bacterial carbon production was calculated using a conversion factor of $1.1 \times 10^{18}$ cells mol$^{-1}$ of thymidine incorporated (Riemann et al. 1987) assuming a cell carbon content of $20 \mathrm{fg} \mathrm{cell}^{-1}$ (Bratbak \& Dundas 1984) and using a conversion factor of $3100 \mathrm{~g} \mathrm{C} \mathrm{mol}^{-1}$ of leucine incorporated (Simon \& Azam 1989).

Bacterial abundance was estimated by epifluorescence microscopy (Hobbie et al. 1977) on DAPI-stained cells filtered on black polycarbonate filters $(0.2 \mu \mathrm{m}$ pore size). Furthermore, to check how many bacterial cells were retained by the $1.2 \mu \mathrm{m}$ pore size filters, bacterial numbers were also counted in the filtrate of the samples.

Lake water chemistry and solar radiation. Data on surface irradiances at the sampling dates (July 1999 to July 2000) and on DOC and radiation attenuation in GKS in July 2000 were provided by R. Sommaruga. Arctic lake samples for DOC measurements were filtered through pre-combusted GF/F filters into combusted glass vials, acidified with $2 \mathrm{~N} \mathrm{HCl}$ to $\mathrm{pH} 2$, and analyzed with a Shimadzu TOC-5000. Surface radiation (PAR) was measured with a Skye quantum sensor. Underwater PAR measurements using a Li-Cor UWQ sensor were made only in NYA. Specific conductivity and $\mathrm{pH}$ were measured with electrodes (WTW LF 196 and WTW pH 91).

\section{RESULTS}

\section{Algal biomass and in situ primary production in GKS}

Throughout the water column, chl a concentrations ranged from $0.6 \pm 0.03$ to $3.9 \pm 1.0 \mu \mathrm{g} \mathrm{l}^{-1}$ in GKS and varied both with depth and season. During summer, a deep chl a maximum was formed $\left(4.6 \mu \mathrm{g}^{-1}\right.$ in $\left.7 \mathrm{~m}\right)$, while under ice-cover, the chl a maximum was at $3 \mathrm{~m}$ depth $\left(4.9 \mu \mathrm{g} \mathrm{l}^{-1}\right)$. Chl a was uniformly distributed throughout the water column in May $\left(0.6 \pm 0.03 \mu \mathrm{g} \mathrm{l}^{-1}\right)$ and October $\left(2.4 \pm 0.2 \mu \mathrm{g} \mathrm{l}^{-1}\right)$. At the $3 \mathrm{~m}$ depth sampled for the solar radiation experiments, chl a concentration increased constantly from $0.6 \mu \mathrm{g}^{-1}$ in May 1999 to $4.9 \mathrm{\mu g} \mathrm{l}^{-1}$ in February 2000 and was low again in May $2000\left(0.7 \mu^{-1} \mathrm{~g}^{-1}\right)$.

Primary production showed a high seasonal variability in GKS. Under ice cover, in situ $\mathrm{P}_{\text {tot }}$ (normalized to chl a) was very low (Fig. 1), ranging between $0.04 \pm$ 0.02 (February 2000) and $0.05 \pm 0.01 \mu \mathrm{g} \mathrm{C}(\mu \mathrm{g} \mathrm{chl} \mathrm{a})^{-1}$ $\mathrm{h}^{-1}$ (May 1999). During the open-water period, $\mathrm{P}_{\text {tot }}$ increased to a maximum of $0.91 \pm 0.02 \mu \mathrm{g} \mathrm{C}(\mu \mathrm{g} \mathrm{chl} \mathrm{a})^{-1}$ $\mathrm{h}^{-1}$ in October 1999. In contrast, the contribution of net PER (\% net PER) to $\mathrm{P}_{\text {tot }}$ was highest in May 1999 (76.9 $\pm 3.9 \%$ ) and decreased continuously to $18.2 \pm 2.9 \%$ in October 1999 (Fig. 1). The lowest \% net PER was estimated in February $2000(7.0 \pm 6.5 \%)$.

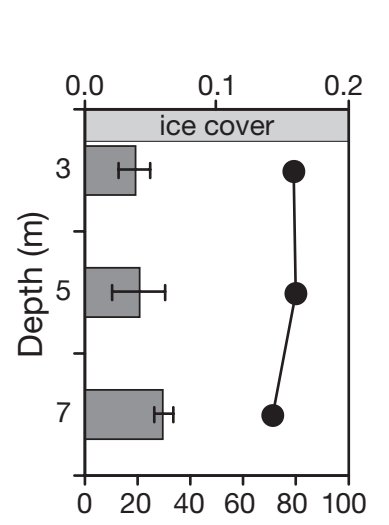

28 May 1999

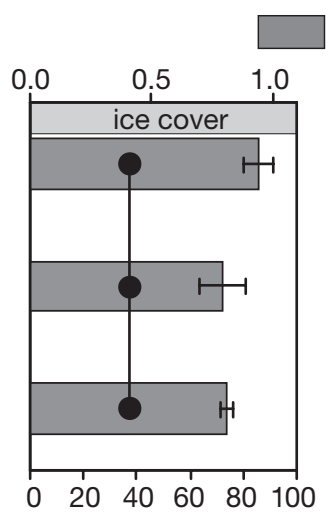

20 Jun 1999 (na)

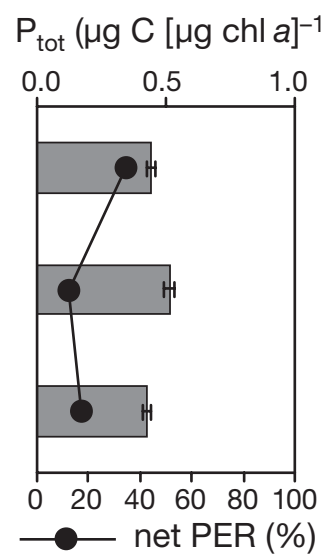

02 Sep 1999

$\left(1241 \mu \mathrm{mol} \mathrm{m}{ }^{-2} \mathrm{~s}^{-1}\right)$

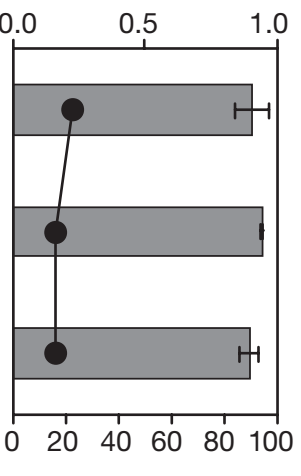

24 Oct 1999 $\left(276 \mu \mathrm{mol} \mathrm{m} \mathrm{m}^{-2} \mathrm{~s}^{-1}\right)$

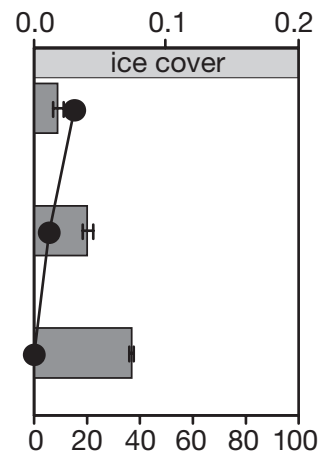

10 Feb 2000 $\left(70 \mu \mathrm{mol} \mathrm{m} \mathrm{m}^{-2} \mathrm{~s}^{-1}\right)$

Fig. 1. Seasonal dynamics of in situ total primary production $\left(\mathrm{P}_{\mathrm{tot}}\right.$ normalized to $\left.\mathrm{chl} a\right)$ and the $\%$ net photosynthetic extracellular release (PER) at 3, 5, and $7 \mathrm{~m}$ in Gossenköllesee (GKS). Note the different scales for $\mathrm{P}_{\text {tot }}$ in May and February. Mean surface irradiance at each sampling date is given in parentheses. Bars indicate mean $\pm \mathrm{SD}(\mathrm{n}=3)$, na: data not available 


\section{Time course of PER and separation efficiency of phyto- vs. bacterioplankton}

The results from the time-course experiment done in October 1999 in GKS suggested that release of photosynthesized carbon was a light-dependent process (Fig. 2). The amount of carbon labeled after $3 \mathrm{~h}$ of light exposure further increased in the light but decreased in the dark in both the $\mathrm{P}_{\text {part } 1}$ and the PER fraction. $\mathrm{P}_{\text {part 2, }}$ however, slightly increased in the light as well as in the dark (Fig. 2). These results indicate that at least in October, $\mathrm{P}_{\text {part } 2}$ was dominated by heterotrophic bacterioplankton that incorporated PER during the incubation. For the other time-course experiments performed in GKS and the Arctic lakes, the amount of labeled carbon within the $\mathrm{P}_{\text {part } 1}$ and PER fractions always increased during light exposure but decreased or remained stable in the dark. $\mathrm{P}_{\text {part 2, }}$ however, showed no clear pattern except that it was always lower in the dark than in the continuous light treatments (results not shown).

Additionally, on several sampling dates, chl $a$ and bacterial numbers were estimated in the filtrate following filtration through $1.2 \mu \mathrm{m}$ pore size filter and compared to the chl a concentration and bacterial abundance in unfiltered samples. The size-fractionated chl a data showed that, on average, $19.9 \pm 14.5 \%$ of the phytoplankton passed the $1.2 \mu \mathrm{m}$ filter with the lowest amount recorded in May 1999 (5.7\%) and the highest in July $2000(40.2 \%)$. From the bacterial cells that varied between 0.3 and $7.7 \times 10^{5} \mathrm{ml}^{-1}$ in GKS, on average $13 \pm$ $11 \%$ were retained by the $1.2 \mu \mathrm{m}$ filter. Similarly to the size-fractionated chl a measurements, the greatest differences (26\% retention) occurred in July 2000; however, no differences between the bacterial abundance in the whole sample and the filtrate were observed in May and July 1999.

To examine the contribution of bacterial incorporated PER in $\mathrm{P}_{\text {part } 2 \text {, this fraction was }}$ compared to the bacterial production rates estimated by leucine- and thymidine-incorporation $\left(\mathrm{BP}_{\text {Leu }}\right.$ and $\left.\mathrm{BP}_{\mathrm{TdR}}\right) . \mathrm{P}_{\text {part } 2}$ mirrored $\mathrm{BP}_{\text {Leu }}$ and $\mathrm{BP}_{\mathrm{TdR}}$ estimated in GKS and in the Arctic lakes (Fig. 3), although $\mathrm{P}_{\text {part } 2}$ represented commonly higher values. The differences between $\mathrm{P}_{\text {part } 2}$ and the bacterial production estimates, however, were in the same order of magnitude as between $\mathrm{BP}_{\text {Leu }}$ and $\mathrm{BP}_{\mathrm{TdR}}$ (Fig. 3). The results obtained with all 3 methods were highly correlated with each other (Spearman rank correlation, $\mathrm{P}_{\text {part } 2}$ and $\mathrm{BP}_{\text {Leu }}$ : $\mathrm{r}=0.854, \mathrm{p}<0.01$; $\mathrm{P}_{\text {part } 2}$ and $\mathrm{BP}_{\mathrm{TdR}}: \mathrm{r}=0.927, \mathrm{p}<0.001 ; \mathrm{BP}_{\text {Leu }}$ and $\left.\mathrm{BP}_{\mathrm{TdR}}: \mathrm{r}=0.976, \mathrm{p}<0.001\right)$ and highly agreed (Kendall W-test, $\mathrm{p}<0.01, \mathrm{n}=8$ ).

\section{PAR effects in GKS}

Depending on their light adaptation, phytoplankton were differently affected by higher than ambient PAR levels (Fig. 4). During the ice-covered season in GKS, the highest primary production was measured at 1 and

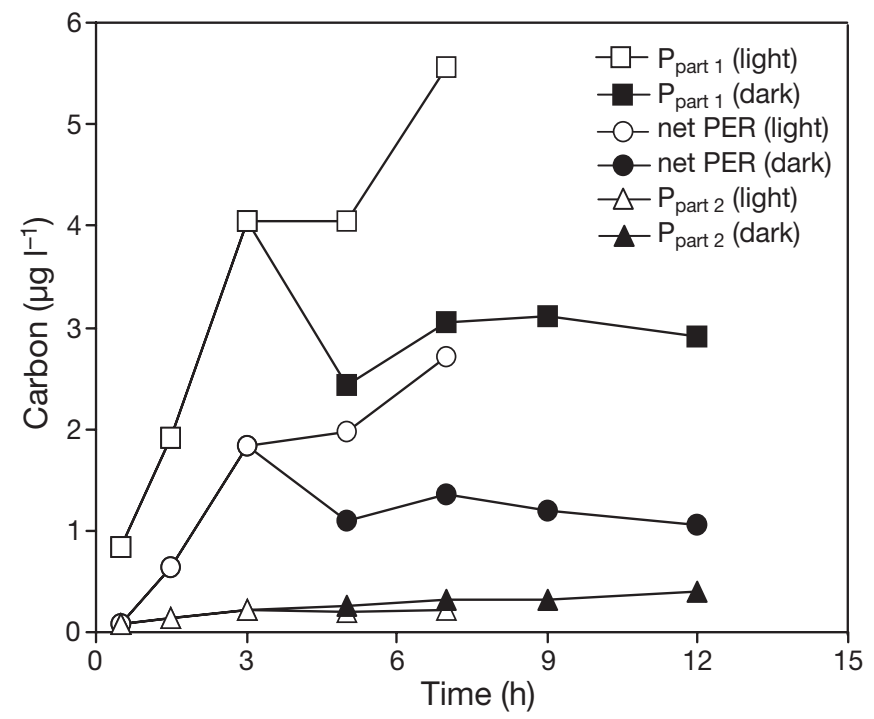

Fig. 2. Time course experiment in GKS performed in October 1999 (samples from $7 \mathrm{~m}$ depth). Amount of labeled carbon in the particulate fractions $\mathrm{P}_{\text {part } 1}(>1.2 \mu \mathrm{m})$ and $\mathrm{P}_{\text {part } 2}(0.2$ to $1.2 \mu \mathrm{m}$ ) and the dissolved fraction (net PER, $<0.2 \mu \mathrm{m}$ ) after continuous incubation in the light or in the dark after $3 \mathrm{~h}$ of light exposure

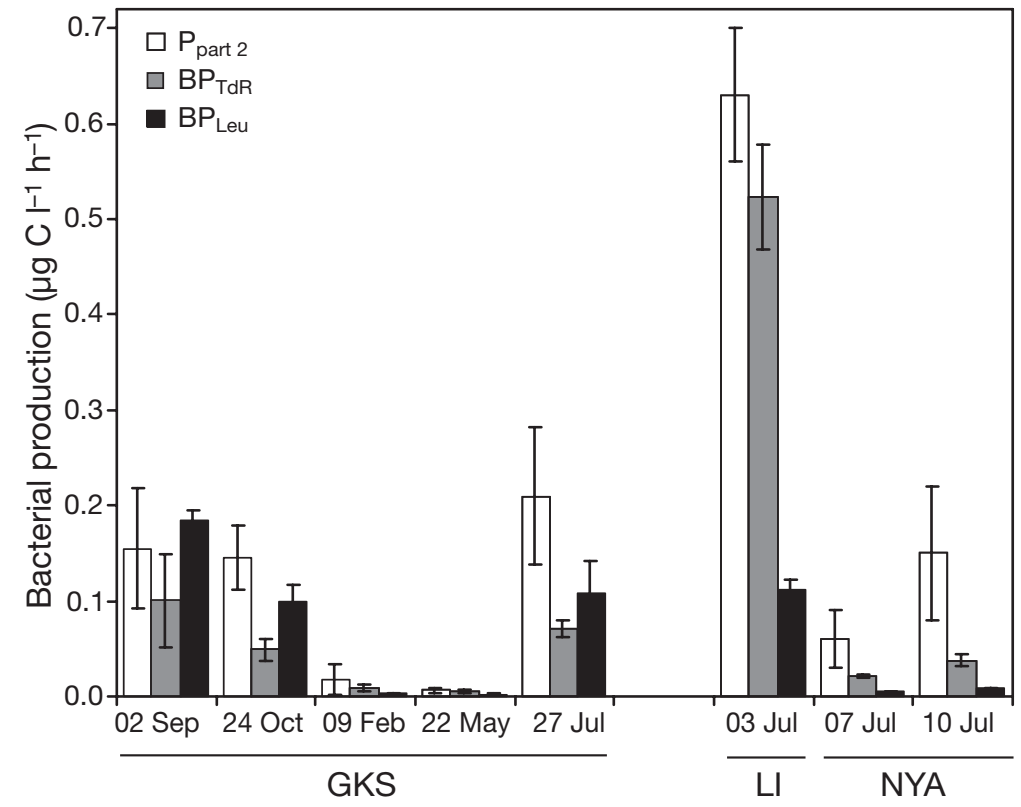

Fig. 3. Comparison of $\mathrm{P}_{\text {part } 2}$ with bacterial production estimated by thymidine $\left(\mathrm{BP}_{\mathrm{TdR}}\right)$ and leucine $\left(\mathrm{BP}_{\text {Leu }}\right)$ incorporation on 5 sampling dates in GKS and in July 2000 in LI and NYA. Bars indicate mean $\pm \mathrm{SD}(\mathrm{n}=3$ to 5$)$ 

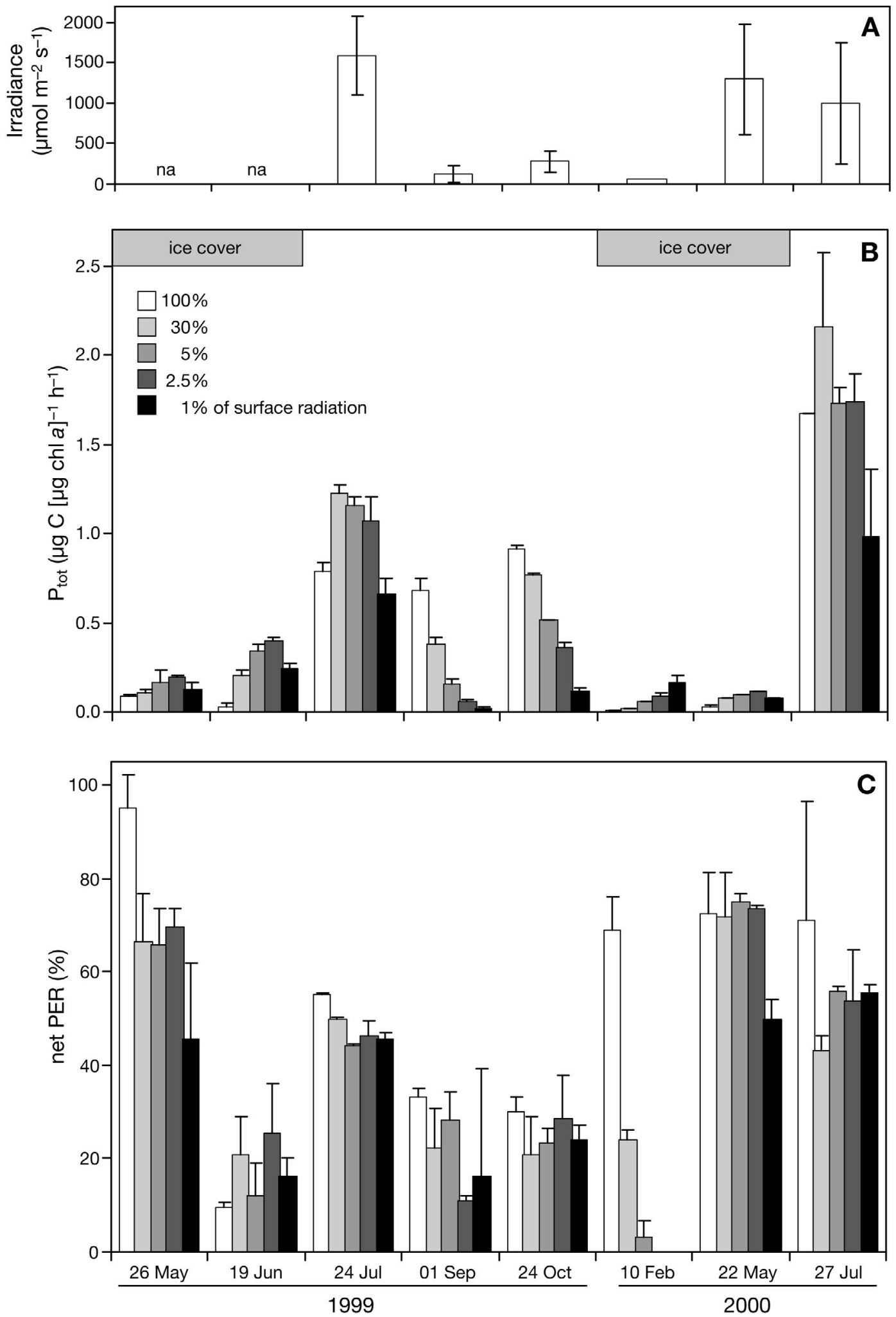

Fig. 4. Annual variability of total primary production ( $\left.\mathrm{P}_{\text {tot }}\right)$ and the percentage of PER (\% net PER) in GKS (samples from $3 \mathrm{~m}$ depth) exposed to $100,30,5,2.5$, and $1 \%$ of surface irradiance. (A) Mean surface irradiance on the sampling dates. (B) $P_{\text {tot }}$ normalized to chl $a_{i}(\mathrm{C}) \%$ net PER at the different irradiances. Bars indicate mean $\pm \mathrm{SD}(\mathrm{A}: \mathrm{n}=29$ to $42 ; \mathrm{B}, \mathrm{C}: \mathrm{n}=2)$; na: data not available 
$2.5 \%$ of the surface radiation level, whereas after iceout with increasing photoacclimatization of phytoplankton, maximum $\mathrm{P}_{\text {tot }}$ occurred at 30 to $100 \%$ of surface radiation (Fig. 4B). Photoinhibition was observed only in July 1999 and 2000 when ambient solar radiation was very high (Fig. 4A, 1584 and $998 \mu \mathrm{mol} \mathrm{m}{ }^{-2} \mathrm{~s}^{-1}$, respectively). The \% net $\mathrm{PER}$, however, was almost always highest at the $100 \%$ irradiance level and generally lower at the low light levels (Fig. 4C). The seasonal fluctuation of \% net PER showed the same pattern as the \% net PER estimated in situ. Average \% net PER obtained during the radiation experiments decreased from May 1999 (69 $\pm 18 \%)$ throughout the summer and autumn (with exceptionally low values in June 1999), was lowest in February (18 $\pm 26 \%)$, and peaked again in May 2000 (69 $\pm 10 \%$; Fig. 4C). However, those maximum values of \% net PER in May refer to only $0.04 \pm 0.02 \mu \mathrm{g} \mathrm{l}^{-1} \mathrm{~h}^{-1}$ in terms of absolute amount of PER. On average, 15 times higher rates of PER were observed during the ice-free season, with a maximum in July $2000\left(1.5 \pm 0.3 \mu \mathrm{g} \mathrm{l}^{-1} \mathrm{~h}^{-1}\right)$.

$\mathrm{P}_{\text {part } 1}$ ranged between $0.012 \pm 0.01$ and $1.04 \pm 0.4 \mu \mathrm{g}$ $\mathrm{l}^{-1} \mathrm{~h}^{-1}$, and $\mathrm{P}_{\text {part } 2}$ ranged between $0.007 \pm 0.002$ and $0.21 \pm 0.06 \mu \mathrm{g} \mathrm{l}^{-1} \mathrm{~h}^{-1}$ during the radiation experiments.

Pooling all data of GKS, the fractions of the primary production measurements (i.e. $\mathrm{P}_{\text {tot }}, \mathrm{P}_{\text {part 1, }} \mathrm{P}_{\text {part 2, net }}$ PER, $\mathrm{P}_{\text {tot }}$ per chl a) were highly significantly correlated (Table 2). Furthermore, a significant inverse relationship between \% net PER and chl a was found (Table 2).

Solar radiation only partially explained the variations in primary production rates in GKS. Net PER production, \% net PER, and $\mathrm{P}_{\text {tot }}$ per chl a correlated with irradiance throughout the annual cycle, while the other fractions including $P_{\text {tot }}$ did not (Table 2). However, seasonally separated data showed different patterns. During the ice-covered period, the \% net PER increased while $\mathrm{P}_{\text {tot }}$ markedly decreased with increasing irradiance (Fig. 5A). When GKS was icefree, both $\mathrm{P}_{\text {tot }}$ and \% net PER were positively related to irradiance (Fig. 5B).
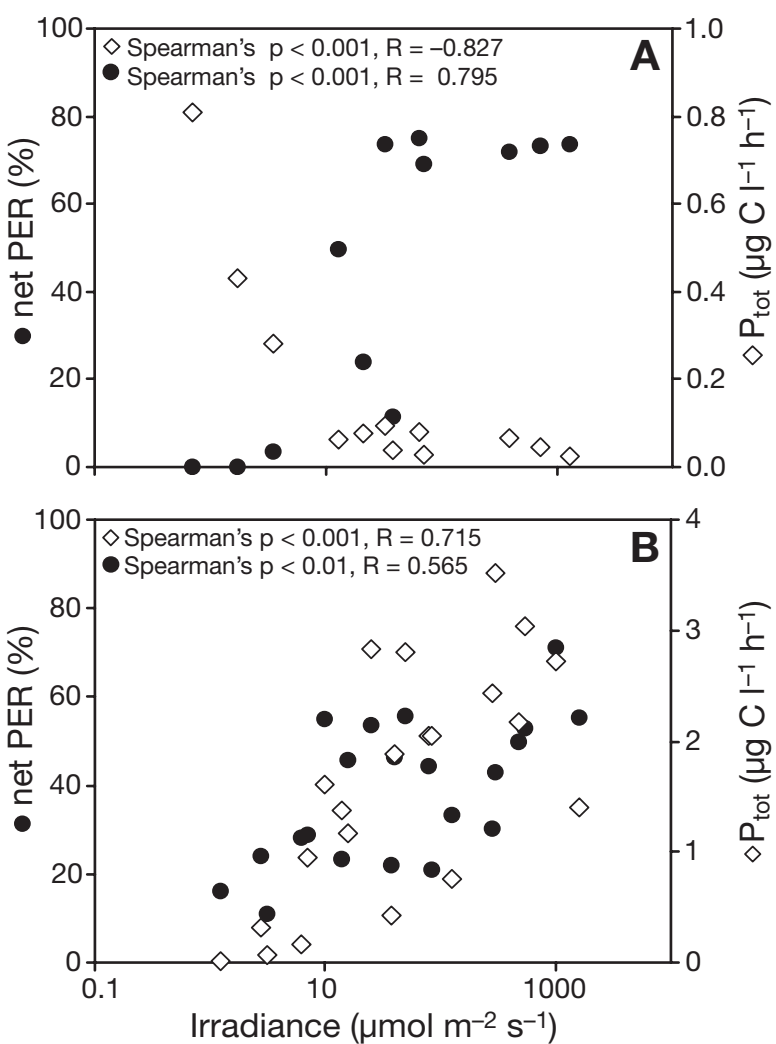

Fig. 5. $\mathrm{P}_{\text {tot }}$ and \% net PER against irradiance. (A) Under ice cover $(\mathrm{n}=12)$. (B) During the open-water period $(\mathrm{n}=21)$. Note scales on $y$-axes differ for $\mathrm{P}_{\text {tot }}$. Significance levels of the relationships are given in the upper left-hand corner

\section{Cross system comparison and UVR effects}

An overview of the physical, chemical, and biological parameters of the investigated alpine and Arctic lakes in July 2000 is presented in Table 3. Unfortunately, UVR data for the Arctic were not available. PAR, however, was comparable among study sites at the time of the radiation experiments (Table 3 ). The

Table 2. Spearman correlation matrix (r) for all data collected between 1999 and 2000 in Gossenköllesee (GKS). PAR: photosynthetically active radiation; see Table 1 for definition of primary production fractions; Chl a: chlorophyll $a_{;} \mathrm{P}_{\text {tot }}$ per chl a: $\mathrm{P}_{\text {tot }}$ normalized to chl $a$. $\mathrm{n}$ is given in parentheses. ${ }^{*} \mathrm{p}<0.05,{ }^{* *} \mathrm{p}<0.01,{ }^{* * *} \mathrm{p}<0.001$

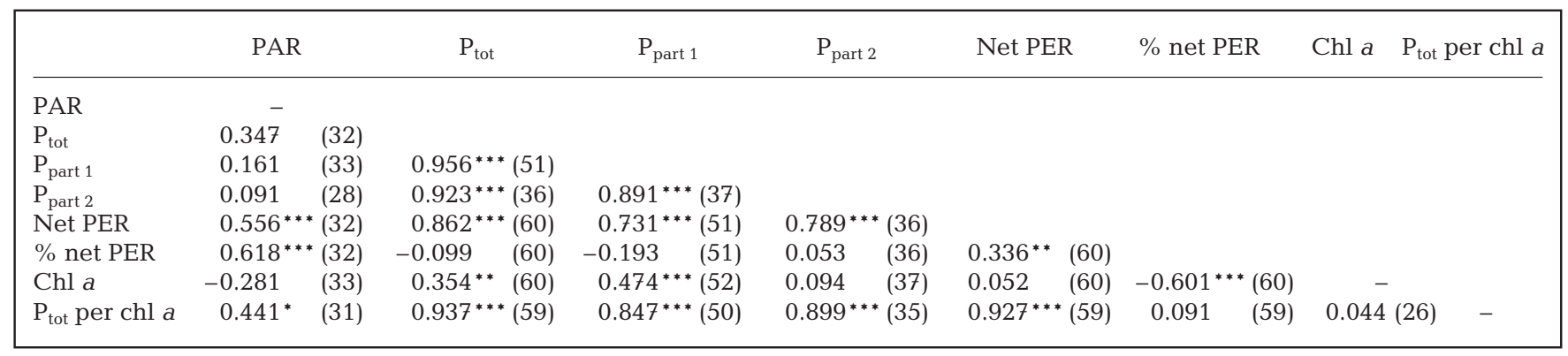


chl a concentrations in the investigated lakes were similar, while primary production normalized to chl a was highest in LI and comparable in NYA and GKS. The concentration of DOC as well as the attenuation coefficients $\left(k_{\mathrm{d}}\right)$ decreased from LI to NYA and GKS (Table 3). The UVR experiments in GKS and the Arctic lakes were conducted at different time intervals to test whether the duration of exposure influences photosynthesis. In all lakes and radiation treatments (PAR, PAR+UVR), primary production rates declined with increasing time of exposure to solar radiation, with the greatest impact observed in LI (35\% reduction of the $24 \mathrm{~h}$ estimates compared to the $6 \mathrm{~h}$ estimates). The impact of incubation time, however, did not differ between the different light treatments. Primary production $\left(\mathrm{P}_{\text {tot }}\right)$ did not vary significantly between the PAR and the PAR+UVR treatments in LI but was significantly inhibited by UVR in GKS and NYA (Fig. 6A). Similar results could be observed concerning $\mathrm{P}_{\text {part } 1}$ (Fig. 6B). In NYA and GKS, net PER contributed about half of the $\mathrm{P}_{\text {tot}}$, while in LI, primary production was dominated by the particulate fractions (Fig. 6). In all lakes, the \% net PER did not greatly vary among the radiation treatments (Fig. 6D). The absolute amount of PER and $\mathrm{P}_{\text {part 2, however, were significantly }}$ reduced in the presence of UVR in GKS (Fig. 6C,E).

\section{DISCUSSION}

\section{Phytoplankton and PER}

Commonly, primary production is measured taking only the particulate production into account. However, not considering the dissolved primary production (i.e. net PER) might lead to gross underestimations of total primary production (Fogg et al. 1965, Chrost \& Faust 1983, Maranón et al. 2004); in GKS, for instance, $P_{\text {tot }}$ would be underestimated by $32 \pm 25 \%$. Although it has been intensively studied, PER by algae is still poorly understood (Bertilsson \& Jones 2003). During this study, active release of carbon occurred only in the light, increasing the amount of PER during light incubation (Fig. 2). In the dark, however, the amount of labeled PER slightly decreased, indicating that phytoplankton stop exudation when exposed to the dark. The fact that PER was primarily performed by healthy, photosynthetically active phytoplankton cells is also supported by the significant relation of PER to $\mathrm{P}_{\text {tot }}$ (Table 2). Similar results have been reported in other studies (Blaauboer et al. 1982, Lancelot 1983, Maranón et al. 2004). However, there are few continuous measurements of PER concentrations under dark conditions (Tilzer \& Horne 1979, Mague et al. 1980). The fact that the production of PER was light-dependent suggests that passive diffusion (Bjørnsen 1988), viral lysis (Brussaard 2004), and 'sloppy feeding' by grazers (Lambert 1978) are only of minor importance for PER at the investigated study sites, since these processes most likely would continue in the dark.

\section{Variability of PER in GKS}

Net PER was highly variable as determined in situ ( 0 to $80 \%$ of in situ $\mathrm{P}_{\text {tot }}$ ) and in the experiments with different radiation regimes ( 0 to $95 \%$ of $P_{\text {tot }}$ ). The $\%$ net PER obtained in GKS is at the upper end of values reported for oligotrophic lakes (e.g. Nalewajko \& Schindler 1976, Tilzer \& Horne 1979, Cole et al. 1982) but similar to values estimated in oligotrophic mountain lakes (Reche et al. 1996, Camarero et al. 1999) and in Antarctic and Arctic lakes (Parker et al. 1977, Panzenböck et al. 2000).

In GKS, a clear seasonal trend in the \% net PER was detected both in situ and for the radiation experiments, with the highest contribution to total production in spring, followed by a decrease during the ice-free sea- 

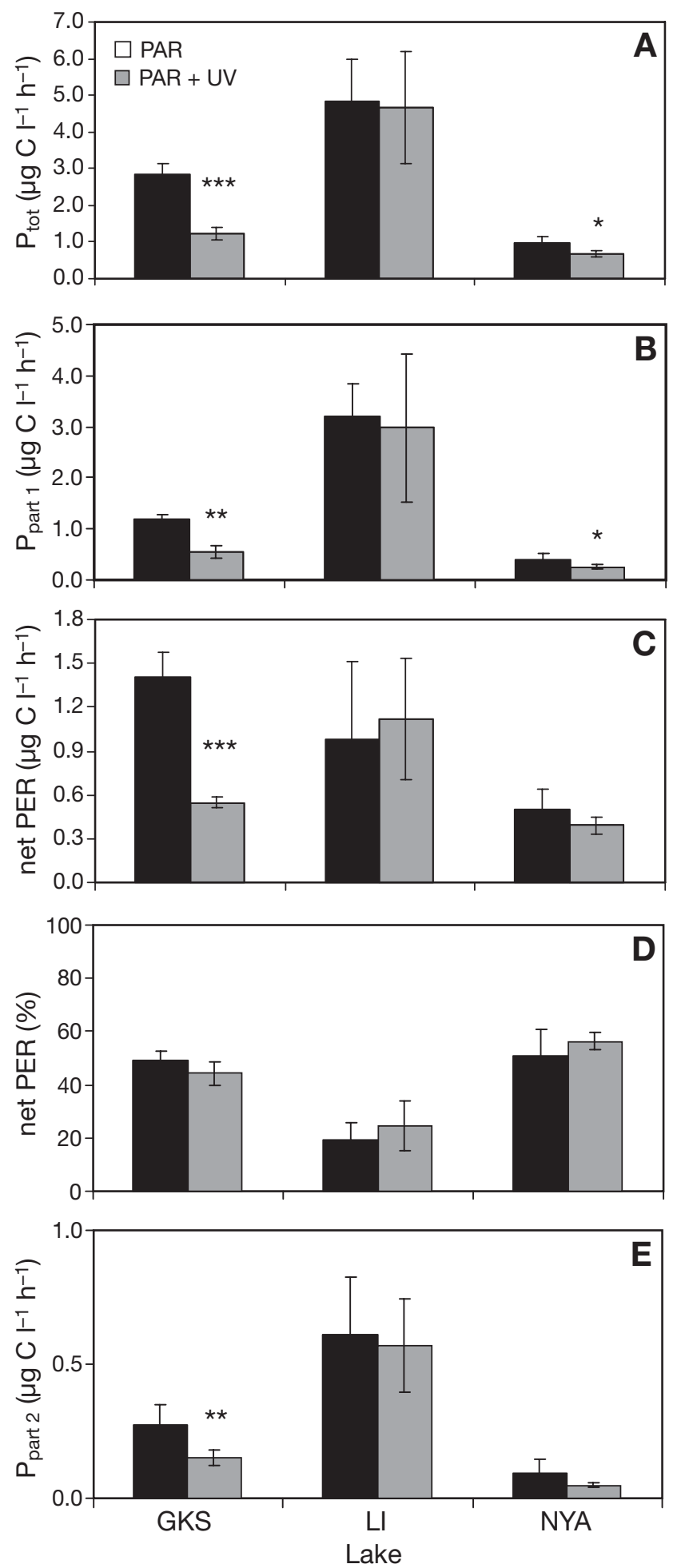

Fig. 6. Fractions of primary production under PAR and PAR + UVR treatments in the 3 lakes (GKS, LI, NYA) in July 2000. (A) Total primary production $\left(\mathrm{P}_{\text {tot }}\right)$; (B) particulate primary production $>1.2 \mu \mathrm{m}\left(\mathrm{P}_{\text {part } 1}\right)$; $(\mathrm{C})$ net $\mathrm{PER}_{i}(\mathrm{D})$ contribution of net PER to $\mathrm{P}_{\text {tot }}(\%$ net PER); (E) particulate primary production 0.2 to $1.2 \mu \mathrm{m}\left(\mathrm{P}_{\text {part } 2}\right)$. Bars indicate mean $\pm \mathrm{SD}(\mathrm{n}=6$ to 9$)$. Significant differences among the light treatments are indicated $(t$-test $):{ }^{*} \mathrm{p}<0.05,{ }^{* *} \mathrm{p}<0.01,{ }^{* * *} \mathrm{p}<0.001$ son and the lowest \% net PER recorded in winter (Figs. 1 \& 4). In line with several studies (Baines \& Pace 1991, Biddanda \& Benner 1997, Carrillo et al. 2002), this seasonal pattern shows that \% net PER is uncoupled from primary production; the pattern of absolute PER, however, resembles that of $\mathrm{P}_{\text {tot }}$ throughout the year (Table 2). Moreover, there was a negative correlation between \% net PER and chl a concentration (Table 2) that has also been noted by other investigators (Berman 1976, Nalewajko \& Schindler 1976, Watanabe 1980, Descy et al. 2002) and implies that on a seasonal scale, senescence and autolysis of phytoplankton cells may lead to a generally larger proportion of PER (Wetzel et al. 1972, Descy et al. 2002, Berman \& Wynne 2005). Moreover, since phytoplankton influence the light attenuation in the water column (Morris et al. 1995, Laurion et al. 2000), low phytoplankton densities may intensify the effects of environmental stress caused, for instance, by high solar radiation. The seasonal pattern of the \% net PER might also be explained by inorganic nutrient availability with nutrient depletion increasing the contribution of PER to $P_{\text {tot }}$ (Fogg 1983, Obernosterer \& Herndl 1995, Pausz \& Herndl 1999).

During this investigation, irradiance was identified as a key factor influencing the PER of phytoplankton in GKS (Table 2). Several studies already reported a higher percentage of PER at elevated irradiances (Fogg et al. 1965, Mague et al. 1980, Fogg 1983) but also at low light levels (Berman 1976, Watanabe 1980, Coveney 1982, Rai 1984). This enhanced PER was often associated with photorespiration producing substantial amounts of glycolate (Fogg et al. 1965, Watanabe 1980). However, conclusions drawn from the \% PER can be misleading, because a constant rate of PER at primary production limited by suboptimal irradiances also results in an increased percentage of PER (Mague et al. 1980, Blaauboer et al. 1982, Lee \& Rhee 1999, Maranón et al. 2004). This seems not to be the case in GKS, because enhanced percentage of PER at low light limitation was not observed (Fig. 5). Moreover, both the \% net PER and the absolute amount of PER significantly correlated with solar radiation intensities (Table 2), supporting the notion that irradiance influences the partitioning of primary production into the particulate and dissolved fraction. Some authors, however, observed no effect of radiation upon PER (Tilzer \& Horne 1979, Blaauboer et al. 1982, Lancelot 1983). This lack of consistency in the findings mentioned above represents a major challenge to arrive at a general conclusion regarding the impact of solar radiation on phytoplankton exudation.

In GKS, the extent of this impact depended on the status of algal photoacclimatization. The most pronounced effect of radiation was observed when phytoplankton were dark-adapted (Fig. 5A). For example, in 
February, the trend of the \% net PER was inverse to that of $\mathrm{P}_{\text {tot }}$ in the radiation experiments (Fig. 4), and a similar pattern was observed in situ, when $\mathrm{P}_{\text {tot }}$ increased while \% net PER decreased with depth (Fig. 1). Here, enhanced carbon release seems to be a consequence of severe light stress as indicated by photoinhibition and is not due to an overflow of photosynthesized carbon as argued by Fogg (1983). When phytoplankton were acclimated to higher light levels, both $\mathrm{P}_{\text {tot }}$ and the net \% PER increased with increasing irradiance (Fig. 5B), indicating that even when photosynthesis is not light-limited, cells release a large portion of their carbon. This may then be considered an imbalance between photosynthesis and algal growth due to nutrient deficiency (Fogg et al. 1965, Berman-Frank \& Dubinsky 1999). Furthermore, phytoplankton may also benefit from these released substances. Azam \& Cho (1987) suggested that exudates create microzones around the algae, promoting bacterial growth and consequently nutrient remineralization. The released carbon, at least that part not metabolized by bacteria, also contributes to the DOC pool known to be a source of light attenuation in the water column (Scully \& Lean 1994, Morris et al. 1995). Although the absorption of algal-derived DOC is generally low compared to DOC of terrestrial origin (McKnight et al. 1994, Laurion et al. 2000), this DOC could possibly be important in waters with low allochthonous input such as GKS due to the poor vegetation and soil development of the alpine catchments (Sommaruga et al. 1999). Moreover, in-lake processes and solar radiation increase the DOC-specific absorption (Reche et al. 2001). Indeed, a strong correlation between DOC and phytoplankton biomass in GKS indicates phytoplankton as an important carbon source (Sommaruga \& Augustin 2006). Although the maximum \% net PER occurred under ice in GKS (Fig. 2), the quantity of PER released during the ice-free period was about 15 times higher than during the icecovered period. The calculation of the contribution of PER to the lake DOC using the mean net PER (4.5 $\mu \mathrm{g}$ $\mathrm{d}^{-1}$ assuming a $10 \mathrm{~h}$ day length) results in a DOC input of $0.13 \mathrm{mg} \mathrm{mo}^{-1}$. This amount is noticeable compared to $0.41 \mathrm{mg} \mathrm{l}^{-1}$ DOC concentration in the lake water in July 2000 and may explain the increase of the DOC concentration between June and August 2000 reported by Sommaruga \& Augustin (2006). However, it remains to be shown whether the attenuation of light by PER is of benefit to the algae.

\section{PER as bacterial carbon supply in GKS}

PER is a readily available carbon and energy source for bacterioplankton (Cole et al. 1982, Coveney 1982). Therefore, the actually measured amount of PER re- presents the net PER, i.e. the fraction of PER not incorporated by bacterioplankton during the incubation. In general, bacterial production is estimated by converting the incorporation rate of thymidine or leucine into carbon production, which was also done during this study. The bacterial utilization of PER, however, can also be measured directly by serial filtration with the inherent difficulty of efficiently separating phyto- and bacterioplankton. While in some lakes picophytoplankton are scarce and unimportant in the 0.2 to $1 \mu \mathrm{m}$ size class (Camarero et al. 1999, Carrillo et al. 2002), in some studies the results were corrected depending on the overlap of the size classes (i.e. Reche et al. 1996). The separation of phyto- and bacterioplankton by serial filtration is especially difficult in GKS, where filamentous bacteria can exceed $>1.2 \mu \mathrm{m}$ (Wille et al. 1999), and picophytoplankton passing the $1.2 \mu \mathrm{m}$ filter are sometimes very abundant. $\mathrm{P}_{\text {part } 1}$ can be assumed to contain large bacterial cells and $\mathrm{P}_{\text {part } 2}$ to contain small algae. The greatest overlap of the size classes $\left(P_{\text {part } 1 \text {, }}\right.$ $P_{\text {part 2) }}$ ) was observed in July as indicated by the high chl a concentration in the $<1.2 \mu \mathrm{m}$ filtrate and the high bacterial numbers retained by the $1.2 \mu \mathrm{m}$ filter. In October, $\mathrm{P}_{\text {part } 2}$ appeared to primarily comprise heterotrophic bacteria, since this fraction increased independent of light conditions, in contrast to $\mathrm{P}_{\text {part 1, which }}$ increased only in the light during the time course (Fig. 2). In comparison to the results obtained by the conventionally used methods, $\mathrm{P}_{\text {part } 2}$ was generally slightly higher than $\mathrm{BP}_{\mathrm{TdR}}$ and $\mathrm{BP}_{\text {Leu, }}$ which may be related to the appearance of picophytoplankton in this fraction. Interestingly, in lakes with scarce picophytoplankton, the BP estimates obtained by PER incorporation were also up to 1 order of magnitude higher than those by leucine or thymidine incorporation, respectively (Camarero et al. 1999, Carrillo et al. 2002). In the present study, the results based on these 3 methods were significantly correlated and were in the same order of magnitude, indicating that the contribution of bacteria retained by the $1.2 \mu \mathrm{m}$ filter roughly equals the phytoplankton biomass passing through this pore size.

Furthermore, the agreement of $\mathrm{P}_{\text {part 2, }} \mathrm{BP}_{\mathrm{TdR}}$, and $\mathrm{BP}_{\text {Leu }}$ implies that PER meets the bacterial carbon demand (BCD) in GKS. A similar conclusion was reached by Reche et al. (1996) for another high-mountain lake and by Panzenböck et al. (2000) for a high Arctic lake. In most studies, however, the amount of PER was insufficient to meet the BCD (Chrzanowski \& Hubbard 1982, Cole et al. 1982, Sondergaard et al. 1985, Baines \& Pace 1991, Descy et al. 2002). Assuming that $P_{\text {part } 2}$ represents bacterially incorporated PER, then 12 to $80 \%$ (mean $37 \%$ ) of the carbon released during the

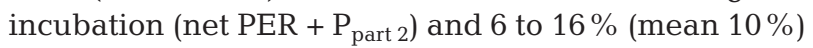
of $\mathrm{P}_{\text {tot }}$ was incorporated into bacterial biomass. As- 
suming a bacterial growth efficiency of $20 \%$ (Smith \& Prairie 2004), 10 to $95 \%$ (mean $58 \%$ ) of the gross PER is channeled through bacteria, corresponding to 25 to $48 \%$ (mean $34 \%$ ) of gross $\mathrm{P}_{\text {tot }}$. Calculating these carbon pathways by $\mathrm{BP}_{\mathrm{TdR}}, 2$ to $35 \%$ (mean $9 \%$ ) of $\mathrm{P}_{\text {tot }}$ was incorporated into bacterial biomass. Assuming a bacterial growth efficiency of $20 \%, 10$ to $73 \%$ of gross $\mathrm{P}_{\text {tot }}$ (mean $28 \%$ ) is channeled through bacteria (based on $\left.\mathrm{BP}_{\mathrm{TdR}}\right)$. These carbon flux estimates are within the range reported in the literature (Cole et al. 1982, Chrost \& Faust 1983, Sondergaard et al. 1985, Camarero et al. 1999).

This also implies, however, that frequently a substantial portion of the PER is not immediately incorporated into bacteria in GKS (on average 63\% of total PER) due to other growth-limiting factors such as low temperatures or UVR (Sommaruga et al. 1997). This carbon remaining in the water column may influence the quantity and quality of the lake DOC (see above).

\section{Cross system comparison}

The values of the biological parameters observed in LI and NYA are typical for Arctic lakes, whereas the primary production rates in LI range among the highest values reported for lakes of similar latitude (Markager et al. 1999, Hobbie et al. 2000, Panzenböck et al. 2000, Ellis-Evans et al. 2001, Laybourn-Parry \& Marshall 2003), even using only the particulate primary production for comparison, since in most of these studies PER was not included in the primary production measurements. In the present study, carbon fixation $\left(\mathrm{P}_{\text {tot }}\right)$ would be underestimated by $21 \%$ in LI and by $51 \%$ in NYA if only the particulate fractions were considered. Thus, similar to the proportions in GKS in summer, net PER comprised about half of the $\mathrm{P}_{\text {tot }}$ in NYA (Fig. 6D). In LI, the \% net PER was much lower, likely due to the higher number of bacteria effectively incorporating PER during the incubation (Fig. 6E). Assuming that $\mathrm{P}_{\text {part } 2}$ primarily comprises bacterial fixed PER, about 37 and $15 \%$ of totally released PER or about 13 and $9 \%$ of $\mathrm{P}_{\text {tot }}$ in LI and NYA, respectively, were incorporated by bacteria. Similarly, $\mathrm{BP}_{\mathrm{TdR}}$ accounted for 34 and $7 \%$ of total PER and for 11 and $4 \%$ of $\mathrm{P}_{\text {tot }}$ in LI and NYA, respectively. Taking the amount of respired PER into account, the carbon flux to bacteria was about 42 and $33 \%$ of gross $\mathrm{P}_{\text {tot }}$ calculated by $\mathrm{P}_{\text {part } 2}$ and about 38 and $16 \%$ based on $\mathrm{BP}_{\mathrm{TdR}}$ in LI and NYA, respectively.

These values also stress the importance of including already metabolized PER into primary production measurements; they are comparable to the carbon flux estimates in GKS (see above) and show that BCD can be met by PER in the investigated Arctic lakes, again indicating the importance of PER for the bacterioplankton carbon and energy demand.

\section{UVR effects and ecosystem implications}

UVR contributes substantially to photoinhibition (Helbling et al. 1992, Milot-Roy \& Vincent 1994). UVR inhibition is likely greater in cold waters, since enzymatically controlled repair mechanisms in cells are temperature-dependent in contrast to the photochemical damage by UVR (Milot-Roy \& Vincent 1994, Doyle et al. 2005). In the present study, primary production was substantially reduced in the presence of UVR in GKS (56\% reduction of $\left.\mathrm{P}_{\text {tot }}\right)$, followed by NYA (30\% reduction of $\mathrm{P}_{\text {tot }}$ Fig. 6A). The extent of the UVR-mediated inhibition is inversely related to the DOC concentration in the investigated lakes (Table 3). In fact, DOC concentration was found to be the main predictor of UVR attenuation in lakes (Scully \& Lean 1994, Morris et al. 1995), whereas the proportion of the CDOM was determined to be primarily responsible for the UVRabsorbing property (Laurion et al. 1997, 2000). Autochthonous sources provide DOC of lower aromaticity than terrestrial-derived DOC (Laurion et al. 2000, Reche et al. 2001, Sommaruga \& Augustin 2006), which may explain the high impact of UVR in GKS (Fig. 6). In contrast, in LI, where UVR exhibited no significant impact on primary production (Fig. 6), the DOC concentration was very high compared to other Arctic lakes (Laurion et al. 1997, Panzenböck et al. 2000, Ellis-Evans et al. 2001). Moreover, this DOC is likely to be dominated by CDOM derived from the terrestrial surroundings with thawing permafrost soil and forest tundra vegetation as indicated by the yellow color of the lake water.

Considering the UVR impact on primary production, it is reasonable to assume that the carbon flux to bacteria via PER is also affected. In GKS, net PER is highly reduced in the presence of UVR (61\% reduction), although \% net PER did not differ among the PAR and PAR+UVR treatments (Fig. 6C,D). This agrees with Pausz \& Herndl (1999), but contrasts to the findings of Carrillo et al. (2002), who reported a higher amount and a higher percentage of PER under elevated UVR conditions. The UVR-mediated reduction of $\mathrm{P}_{\text {part } 2}$ averaged $45 \%$ in GKS and $48 \%$ in NYA (Fig. 6E). Assuming $\mathrm{P}_{\text {part } 2}$ primarily comprises bacteria, this could be the result of direct UVR-induced inhibition of bacterioplankton (Herndl et al. 1993, Sommaruga et al. 1997) or due to indirect effects, as there is a lower amount of PER available for bacteria that can become less bioavailable upon exposure to solar radiation (Pausz \& Herndl 1999, Obernosterer et al. 2001). This 
reduced carbon flux to the microbial loop with likely cascading effects to higher trophic levels (Rae \& Vincent 1998) might be especially important in the investigated lakes, since Arctic and alpine regions are thought to experience increased UV-B radiation (Blumthaler et al. 1992, Vincent \& Pienitz 1996). However, since global warming is believed to increase inputs of allochthonous DOC and consequently radiation attenuation in high altitude and latitude lakes (Sommaruga et al. 1999, Pienitz \& Vincent 2000), this process may compensate the negative impact of UVR to a certain extent. Therefore, a description of future scenarios under the impact of global change remains difficult.

Since underwater light measurements were not possible in LI and in the UVR-wavelengths in NYA, the attenuations coefficients $\left(k_{\mathrm{d}}\right)$ presented in Table 3 were partly estimated from the DOC measurements applying the equation of Morris et al. (1995). The calculated $k_{\mathrm{dPAR}}(0.50)$ for NYA corresponded to the measured $k_{\mathrm{dPAR}}(0.54)$ obtained in NYA. Moreover, the DOC concentrations in the Arctic lakes were well above $2 \mathrm{mg} \mathrm{l}^{-1}$, a range for which this equation seems to provide realistic $K_{d}$ values (Laurion et al. 1997, Sommaruga et al. 1999). Comparing the investigated lakes, UVR and PAR penetration was greatest in GKS among the most transparent lakes reported in the literature (e.g. Morris et al. 1995, Laurion et al. 2000). The depth at which UV-B ${ }_{320}$ radiation, for instance, was attenuated to the $1 \%$ level of incident intensity $\left(z_{1 \%}\right)$ was $18.3 \mathrm{~m}$ in GKS on 27 July 2000, which means that all of the phyto- and bacterioplankton present in the water column were exposed to high UVR on this date. In contrast, the $k_{\mathrm{d}}$ values for the Arctic lakes (Table 3) were at the upper end of ranges reported for Arctic lakes (Laurion et al. 1997, Markager et al. 1999, EllisEvans et al. 2001), but well within the values reported for subarctic and temperate lakes (Scully \& Lean 1994, Laurion et al. 1997). Thus, the $z_{1 \%}$ of UV-B $B_{320}$ ranged between $0.3 \mathrm{~m}$ in LI and $0.8 \mathrm{~m}$ NYA on the sampling date, indicating that in both Arctic lakes, UV-B is completely attenuated within the upper $1 \mathrm{~m}$ of the water column.

In conclusion, the phytoplankton in GKS were found to increase the contribution of net PER when exposed to higher irradiances, whereas enhanced PER seemed to be (1) a consequence of severe light stress of dark adapted algae and (2) a mechanism uncoupled from photoinhibition during the ice-free seasons, possibly improving the conditions for photosynthesis and algal growth. The greatly varying \% net PER (in situ 0 to $80 \%$ of $\mathrm{P}_{\text {tot }}$ ) was inversely related to chl $a$. On average, more than half of the released carbon was not used by bacteria and may be an important contribution to the DOC in the water column in GKS. In the Arctic lakes,
$\%$ net PER ranged between 21 and $51 \%$ in July. In all lakes, PER seems to fulfill the BCD. While \% net PER was not affected by UVR, primary production and PER were suppressed by UVR dependent on the DOC concentration in the investigated lakes, with the greatest effect observed in GKS (56\% reduction of $\mathrm{P}_{\text {tot, }} 61 \%$ reduction of PER). Thus, DOC-poor high altitude lakes appear more sensitive to UVR radiation and its predicted changes than high-DOC Arctic lakes.

Acknowledgements. I thank R. Psenner, B. Sattler, and A. Wille for logistic support and help during field and laboratory work, A. Richter for organizing the expedition to Siberia, and R. Sommaruga for providing data (DOC, radiation) from Gossenköllesee (Austria). The comments of G. J. Herndl, R. Sommaruga, R. Psenner, and 3 anonymous reviewers were greatly appreciated. This research was funded by the Austrian Science Foundation (FWF P11686-BIO) and the expedition financed by the Austrian Ministry of Education, Science, and Culture. This work is in partial fulfilment of the requirements towards the $\mathrm{PhD}$ degree at the University of Vienna by M.P.

\section{LITERATURE CITED}

Azam F, Cho BC (1987) Bacterial utilization of organic matter in the sea. In: Fletcher M, Gray CRG, Jones JG (eds) Ecology of microbial communities. Cambridge University Press, Cambridge, p 261-281

Baines SB, Pace ML (1991) The production of dissolved organic matter by phytoplankton and its importance to bacteria: patterns across marine and freshwater systems. Limnol Oceanogr 36 (6):1078-1090

Beniston M, Diaz HF, Bradley RS (1997) Climatic change at high elevation sites: an overview. In: Diaz HF, Beniston M, Bradley RS (eds) Climatic change at high elevation sites. Kluwer Academic, Dordrecht, p 1-19

Berman T (1976) Release of dissolved organic matter by photosynthesizing algae in Lake Kinneret, Israel. Freshw Biol 6:13-18

Berman T, Wynne D (2005) Assessing phytoplankton lysis in Lake Kinneret. Limnol Oceanogr 50(2):526-537

Berman-Frank I, Dubinsky Z (1999) Balanced growth in aquatic plants: myth or reality? BioScience 49:29-37

Bertilsson, S, Jones JB Jr (2003) Supply of dissolved organic matter to aquatic ecosystems: autochthonous sources. In: Findlay SEG, Sinsabaugh RL (eds) Aquatic ecosystems. Interactivity of dissolved organic matter. Academic Press, San Diego, CA, p 3-24

Biddanda B, Benner R (1997) Carbon, nitrogen, and carbohydrate fluxes during the production of particulate and dissolved organic matter by marine phytoplankton. Limnol Oceanogr 42(3):506-518

Bjørnsen, PK (1988) Phytoplankton exudation of organic matter: Why do healthy cells do it? Limnol Oceanogr 33(1): 151-154

Blaauboer MC, van Keulen R, Cappenberg THE (1982) Extracellular release of photosynthetic products by freshwater phytoplankton populations with special reference to the algal species involved. Freshw Biol 12:559-572

Blumthaler M, Ambach W, Rehwald W (1992) Solar UV-A and UV-B radiation fluxes at two alpine stations at different altitudes. Theor Appl Clim 46:39-44 
Bratbak G, Dundas I (1984) Bacterial dry matter content and biomass estimations. Appl Environ Microbiol 48(4):755757

Brussaard CPD (2004) Viral control of phytoplankton populations - a review. J Eukaryot Microbiol 51:125-138

Camarero L, Felip M, Ventura M, Bartumeus F, Catalan J (1999) The relative importance of the planktonic food web in the carbon cycle of an oligotrophic mountain lake in a poorly vegetated catchment (Redo, Pyrenees). J Limnol 58(2):203-212

Carrillo P, Medina-Sánchez JM, Villar-Argaiz M (2002) The interaction of phytoplankton and bacteria in a high mountain lake: importance of the spectral composition of solar radiation. Limnol Oceanogr 47(5):1294-1306

Chrost RH, Faust MA (1983) Organic carbon release by phytoplankton: its composition and utilization by bacterioplankton. J Plankton Res 5(4):477-493

Chrzanowski TH, Hubbard JG (1989) Bacterial utilization of algal extracellular products in a southwestern reservoir. Hydrobiologia 179:61-71

Cole JJ, Likens GE, Strayer DL (1982) Photosynthetically produced dissolved organic carbon: an important carbon source for planktonic bacteria. Limnol Oceanogr 27(6): 1080-1090

Coveney MF (1982) Bacterial uptake of photosynthetic carbon from freshwater phytoplankton. Oikos 38:8-20

Descy JP, Leporcq B, Viroux L, Francois C, Servais P (2002) Phytoplankton production, exudation and bacterial reassimilation in the River Meuse (Belgium). J Plankton Res 24(3):161-166

Doyle SA, Saros JE, Williamson CE (2005) Interactive effects of temperature and nutrient limitation on the response of alpine phytoplankton growth to ultraviolet radiation. Limnol Oceanogr 50(5):1362-1367

Ellis-Evans JC, Galchenko V, Laybourn-Parry J, Mylnikov AP, Petz W (2001) Environmental characteristics and microbial plankton activity of freshwater environments at Kongsfjorden, Spitsbergen (Svalbard). Arch Hydrobiol 152:609-632

Fogg GE (1983) The ecological significance of extracellular products of phytoplankton photosynthesis. Bot Mar 26: $3-14$

Fogg GE, Nalewajko C, Watt WD (1965) Extracellular products of phytoplankton photosynthesis. Proc R Soc Lond Ser B 162:517-534

Fuhrman JA, Azam F (1980) Bacterioplankton secondary production estimates for coastal waters of British Columbia, Antarctica, and California. Appl Environ Microbiol 39(6): 1085-1095

Giroldo D, Vieira AAH (1999) Assimilation and release of ${ }^{14} \mathrm{C}$ in a tropical strain of Cryptomonas obovata (Cryptophyceae) exposed to several irradiances. J Plankton Res 21(10):1911-1921

Helbling EW, Villafañe V, Ferrario M, Holm-Hansen O (1992) Impact of natural ultraviolet radiation on rates of photosynthesis and on specific marine phytoplankton species. Mar Ecol Prog Ser 80:89-100

Hellebust JA (1974) Extracellular products. In: Stewart WDP (ed) Algal physiology and biochemistry. Blackwell Scientific Publications, Oxford, p 838-863

Herndl GJ, Müller-Niklas G, Frick J (1993) Major role of ultraviolet-B in controlling bacterioplankton growth in the surface layer of the ocean. Nature 361:717-719

Hobbie JE, Corliss T, Peterson B (1977) Use of Nucleoporefilters for counting bacteria by fluorescence microscopy. Appl Environ Microbiol 33:1225-1228

Hobbie JE, Bahr M, Bettez N, Rublee PA (2000) Microbial food webs in oligotrophic arctic lakes. Microbial biosys- tems: new frontiers. In: Bell CR, Brylinsky M, JohnsonGreen M (eds) Proceedings of the 8th International Symposium on Microbial Ecology. Atlantic Canada Society for Microbial Ecology, Halifax, p 293-298

Lambert W (1978) Release of dissolved organic carbon by grazing phytoplankton. Limnol Oceanogr 23:831-834

Lancelot C (1983) Factors affecting phytoplankton extracellular release in the Southern Bight of the North Sea. Mar Ecol Prog Ser 12:115-121

Laurion I, Vincent WF, Lean DRS (1997) Underwater ultraviolet radiation: development of spectral models for northern high latitude lakes. Photochem Photobiol 65(1): $107-114$

Laurion I, Ventura M, Catalan J, Psenner R, Sommaruga R (2000) Attenuation of ultraviolet radiation in mountain lakes: factors controlling the among- and within-lake variability. Limnol Oceanogr 45(6):1274-1288

Laybourn-Parry J, Marshall WA (2003) Photosynthesis, mixotrophy and microbial plankton dynamics in two high Arctic lakes during summer. Polar Biol 26(8):517-524

Lee DY, Rhee GY (1999) Kinetics of growth and death in Anabaena flos-aquae (Cyanobacteria) under light limitation and supersaturation. J Phycol 35:700-709

Lignell R (1992) Problems of filtration fractionation of ${ }^{14} \mathrm{C}$ primary productivity samples. Limnol Oceanogr 37(1): 172-178

Livingstone DM (1997) Break-up dates of alpine lakes as proxy data for local and regional mean surface air temperatures. Clim Change 37:407-439

Mague TH, Friberg E, Hughes DJ, Morris I (1980) Extracellular release of carbon by marine phytoplankton; a physiological approach. Limnol Oceanogr 25 (2):262-279

Maranón E, Cermeno P, Fernández E, Rodriguez J, Zabala L (2004) Significance and mechanisms of photosynthetic production of dissolved organic carbon in a coastal eutrophic ecosystem. Limnol Oceanogr 49(5):1652-1666

Markager S, Vincent WF, Tang EPY (1999) Carbon fixation by phytoplankton in high Arctic lakes: implications of low temperature for photosynthesis. Limnol Oceanogr 44(3): 597-607

McKnight DM, Andrews ED, Spaulding, SA, Aiken GR (1994) Aquatic fulvic acids in algal-rich Antarctic ponds. Limnol Oceanogr 39(8):1972-1979

Milot-Roy V, Vincent WF (1994) UV radiation effects on photosynthesis: the importance of near-surface thermoclines in a subarctic lake. Arch Hydrobiol Beih Ergeb Limnol 43: 171-184

Morris DP, Zaarese $\mathrm{H}$, Williamson CE, Balseiro EG, Hargreaves BR, Modenutti B, Moeller R, Queimalinos C (1995) The attenuation of solar UV radiation in lakes and the role of dissolved organic carbon. Limnol Oceanogr 40(8):1381-1391

Nalewajko C, Schindler DW (1976) Primary production, extracellular release, and heterotrophy in two lakes in the ELA, Northwestern Ontario. J Fish Res Board Can 33: 219-226

Obernosterer I, Herndl GJ (1995) Phytoplankton extracellular release and bacterial growth: dependence on the inorganic N:P ratio. Mar Ecol Prog Ser 116:247-257

Obernosterer I, Sempére R, Herndl GJ (2001) Ultraviolet radiation induces reversal of the bioavailability of DOM to marine bacterioplankton. Aquat Microb Ecol 24:61-68

Panzenböck M, Möbes-Hansen B, Albert R, Herndl GJ (2000) Dynamics of phyto- and bacterioplankton in a high Arctic lake on Franz Joseph Land archipelago. Aquat Microb Ecol 21:265-273

Parker BC, Hoehn RC, Paterson RA, Craft JA and 6 others 
(1977) Changes in dissolved organic matter, photosynthetic production, and microbial community composition in Lake Bonney, Southern Victoria Lane, Antarctica. In: Llano GS (ed) Adaptations within Antarctic ecosystems. Gulf Publishing, Houston, TX, p 873-890

Parsons T, Maita Y, Lalli C (1984) A manual of chemical and biological methods for seawater analysis. Pergamon Press, Oxford

Pausz C, Herndl GJ (1999) Role of ultraviolet radiation on phytoplankton extracellular release and its subsequent utilization by marine bacterioplankton. Aquat Microb Ecol 18:85-93

Pienitz R, Vincent WF (2000) Effect of climate change relative to ozone depletion on UV exposure in subarctic lakes. Nature 404:484-487

Rae R, Vincent WF (1998) Effects of temperature and ultraviolet radiation on microbial foodweb structure: potential responses to global change. Freshw Biol 40:747-758

Rai H (1984) Release of photosynthetically produced dissolved organic carbon by natural phytoplankton populations in Schöhsee. Verh Int Ver Limnol 22:936-942

Reche L, Pugnetti A, Cruz-Pizarro L, Carrillo P (1996) Relationship between bacteria and phytoplankton in a highmountain lake: importance of the organic carbon released by pelagic algae for bacterioplankton. Arch Hydrobiol Spec Iss Adv Limnol 48:31-38

Reche L, Pulido-Villena E, Conde-Porcuna JM, Carrillo P (2001) Photoreactivity of dissolved organic matter from high-mountain lakes of Sierra Nevada, Spain. Arct Antarct Alp Res 33(4):426-434

Reitner B, Herzig A, Herndl GJ (2002) Photoreactivity and bacterioplankton availability of aliphatic versus aromatic amino acids and a protein. Aquat Microb Ecol 26:305-311

Riemann B, Bjørnsen PK, Newell S, Fallen R (1987) Calculation of cell production of coastal marine bacteria based on measured incorporation of $3 \mathrm{H}$ thymidine. Limnol Oceanogr 32(2):471-476

Scully NM, Lean DRS (1994) The attenuation of ultraviolet radiation in temperate lakes. Arch Hydrobiol Beih Ergeb Limnol 43:135-144

Simon M, Azam F (1989) Protein content and protein synthesis rates of planktonic marine bacteria. Mar Ecol Prog Ser 51:201-213

Editorial responsibility: Lars Tranvik, Uppsala, Sweden
Smith EM, Prairie YT (2004) Bacterial metabolism and growth efficiency in lakes: the importance of phosphorus availability. Limnol Oceanogr 49(1):137-147

Sommaruga R, Augustin G (2006) Seasonality in UV transparency of an alpine lake is associated to changes in phytoplankton biomass. Aquat Sci 68:129-141

Sommaruga R, Obernosterer I, Herndl GJ, Psenner R (1997) Inhibitory effect of solar radiation on thymidine and leucine incorporation by freshwater and marine bacterioplankton. Appl Environ Microbiol 63(11):4178-4184

Sommaruga R, Psenner R, Schafferer E, Koinig KA, Sommaruga-Wögrath S (1999) Dissolved organic carbon concentration and phytoplankton biomass in high-mountain lakes of the Austrian Alps: potential effect of climatic warming on UV under water attenuation. Arct Antarct Alp Res 31(3):247-253

Sondergaard M, Riemann B, Jørgensen NOG (1985) Extracellular organic carbon (EOC) released by phytoplankton and bacterial production. Oikos 45:323-332

Strickland JDH, Parsons TR (1972) A practical handbook of seawater analysis, 2nd edn. Bull Res Board Can 167

Tilzer MM, Horne AJ (1979) Diel patterns of phytoplankton productivity and extracellular release in ultra-oligotrophic Lake Tahoe. Int Rev Gesamten Hydrobiol 64(2):157-176

Vincent WF, Pienitz R (1996) Sensitivity of high latitude freshwater ecosystems to global change: temperature and solar ultraviolet radiation. Geosci Can 23:231-236

von Elert E, Jüttner F (1997) Phosphorus limitation and not light controls the extracellular release of allelopathic compounds by Trichormus doliolum (Cyanobacteria). Limnol Oceanogr 42(8):1796-1802

Watanabe Y (1980) A study of excretion and extracellular products of natural phytoplankton in Lake Nakanuma, Japan. Int Rev Gesamten Hydrobiol 65:809-834

Wetzel RG (1995) Limnological analyses. Springer, New York, NY

Wetzel RG, Rich PH, Miller MC, Allen HL (1972) Metabolism of dissolved and particulate detrital carbon in a temperate hardwater lake. Mem Ist Ital Idrobiol 29:185-243

Wille A, Sonntag B, Sattler B, Psenner R (1999) Abundance, biomass and size structure of the microbial assemblage in the high mountain lake Gossenköllesee (Tyrol, Austria) during the ice-free period. J Limnol 58(2):117-126

Submitted: November 15, 2006; Accepted: April 23, 2007

Proofs received from author(s): June 19, 2007 